\title{
REKAYASA SISTEM INFORMASI MANAJEMEN PANTI ASUHAN MUHAMMADIYAH SUMBAWA BERBASIS WEB
}

\author{
Nawassyarif ${ }^{1}$, Nora Dery Sofya ${ }^{2}$, Siti Kalkausar Djafar HS $^{3^{*}}$, Eri Sasmita Susanto ${ }^{4}$ \\ 1,2,3,4 Program Studi Teknik Informatika, Universitas Teknologi Sumbawa \\ email: sitikalkausar@gmail.com*
}

\begin{abstract}
Abstrak: Panti Asuhan Muhammadiyah merupakan lembaga kesejahteraan sosial yang membentuk tumbuh kembang anakanak yang tidak mempunyai keluarga ataupun yang tidak tinggal bersama dengan keluarga. Sistem manajemen data yang berjalan pada Panti Asuhan Muhammadiyah saat ini masih merepotkan pengurus dengan dicatat dalam buku besar dan microsoft office word. Pengolahan data seperti ini tentu akan menyulitkan pengurus dalam penyajian laporan karena membutuhkan waktu yang relatif lama sehingga memungkinkan terjadinya kesalahan dalam pengelolaan data. Selain itu tidak adanya informasi lengkap mengenai Panti Asuhan Muhammadiyah sehingga donatur harus datang ke panti untuk mendapatkan informasi. Tujuan dari penelitian skripsi ini yaitu Rekayasa Sistem Informasi Manajemen Panti Asuhan Muhammadiyah Sumbawa Berbasis Web. Sistem ini berhasil dirancang dan dibangun dengan menggunakan bahasa pemrograman PHP, HTML, CSS, Database MySQL, Text Editor Sublime-Text, metode penelitian kualitatif serta menggunakan metode pengembangan perangkat lunak Waterfall. Hasil dari penelitian ini adalah Sistem Informasi Manajemen Panti Asuhan Muhammadiyah Sumbawa Berbasis Web yang dapat mempermudah pengurus dalam mengelola data panti asuhan serta mempermudah donatur dalam mencari informasi mengenai Panti Asuhan Muhammadiyah.
\end{abstract}

Kata Kunci : Panti Asuhan Muhammadiyah Sumbawa, Sistem Informasi Manejemen, Waterfall, Web.

Abstract: Muhammadiyah Orphanage is a social welfare institution that shapes the growth and development of children who do not have families or who do not live with their families. The data management system currently running at the Muhammadiyah Orphanage is still manual which is recorded in a ledger and microsoft office word. Data processing like this will certainly make it difficult for administrators to present reports because it takes a relatively long time so as to allow errors in data management. In addition, there is no complete information about the Muhammadiyah orphanage so that donors must come to the orphanage to get information. The purpose of this thesis research is the Web-Based Engineering Information System of Muhammadiyah Sumbawa Orphanage Management. This system successfully designed and built using programming language PHP, HTML, CSS, MySQL Database, Sublime-Text Text Editor, qualitative research methods and using the Waterfall software development method. The final result of this thesis is Muhammadiyah Orphanage Management Information System Sumbawa Web-Based that will make it easier for administrators to manage orphanage data and make it easier for donors to find information about Muhammadiyah orphanages.

Keywords : Panti Asuhan Muhammadiyah Sumbawa, Management Information System, Waterfall, Web

\section{PENDAHULUAN}

Teknologi komputer dan internet saat ini bukan lagi suatu hal yang mahal dan sulit untuk beberapa kalangan masyarakat, tetapi sudah menjadi kebutuhan yang sangat penting untuk memproses dan bertukar informasi dalam skala lokal, nasional maupun global.

Penggunaannya tidak hanya fokus pada satu tujuan, melainkan untuk berbagai tujuan dan kegunaannya dapat dimanfaatkan dalam lembaga sosial, dunia bisnis maupun yang lainnya. Dalam lembaga sosial seperti panti asuhan, penggunaan teknologi komputer dan internet salah satunya dapat dimanfaatkan untuk membuat sistem informasi yang dapat memudahkan manajemen panti.

Panti asuhan merupakan suatu lembaga pelayanan sosial untuk memelihara dan merawat anak-anak yang tidak mempunyai keluarga ataupun yang tidak tinggal bersama dengan keluarga. Panti Asuhan Muhammadiyah adalah salah satu lembaga sosial yang berada di Sumbawa, NTB. Panti asuhan ini mengasuh anak-anak dari keluarga kurang mampu dan yatim piatu disekitar Sumbawa. Anak-anak panti asuhan dirawat oleh pengasuh yang menggantikan peran orang tua dalam merawat, menjaga dan memberikan bimbingan kepada anak agar menjadi manusia dewasa yang berguna dan bertanggung jawab atas dirinya dan terhadap masyarakat di masa yang akan datang.

Sistem manajemen data yang berjalan pada Panti Asuhan Muhammadiyah saat ini masih bersifat manual yang dicatat dalam buku besar dan microsoft office word. Pencatatannya seperti data anak panti, data donasi, data pengurus, serta laporan triwulan. Pada saat ini, jumlah anak panti yang tinggal di panti sebanyak 30 orang dan sebanyak 20 orang berada di asrama dan masih dipantau oleh pihak pengurus. Hal ini dikarenakan panti hanya dapat menampung sebanyak 30 orang anak. Para donatur yang ingin menyumbang donasi harus datang langsung ke panti dan kemudian akan dicatat datanya dalam buku besar oleh pihak pengurus. Pengolahan data seperti ini tentu akan menyulitkan pengurus dalam penyajian laporan karena membutuhkan waktu yang relatif lama sehingga memungkinkan terjadinya kesalahan dalam pengelolaan data. Masalah lain yang dihadapi panti saat ini ialah untuk memperoleh dana dari donatur, Panti Asuhan Muhammadiyah melakukan penyebaran informasi melalui interaksi langsung dengan masyarakat, media sosial facebook serta 
penyebaran kartu nama. Selain itu tidak adanya informasi lengkap mengenai Panti Asuham Muhammadiyah sehingga donatur harus datang ke panti untuk mendapatkan informasi. Dengan memanfaatkan teknologi dan internet para donatur dan masyarakat dapat dengan mudah mengakses sistem informasi dimanapun dan kapanpun [1] [2].

Berdasarkan masalah tersebut, penulis menawarkan sebuah Rekayasa Sistem Informasi Manajemen Panti Asuhan Muhammadiyah Sumbawa Berbasis Web. Diharapkan dengan adanya sistem ini dapat mempermudah pengurus panti dalam mengelolah data Panti Asuhan secara cepat dan akurat. Selain itu dapat mempermudah donatur dalam mencari informasi mengenai Panti Asuhan Muhammadiyah.

\section{TINJAUAN PUSTAKA}

Adapun beberapa penelitian terkait sebelumnya yang serupa yaitu yang pertama dengan judul Rancangan Sistem Informasi Manajemen Sekolah Berbasis Web Interaktif Terintegrasi Di Smk Negeri 1 Nabire. Metode pengembangan perangkat lunak berorientasi objek dan metode pengumpulan data berupa observasi, wawancara, studi pustaka dandokumentasi. Sistem informasi manajemen sekolah berbasis web interaktif terintegrasi di SMK Negeri 1 Nabire telah berhasil dibuat dan memberikan manfaat kepada masyarakat dan pihak sekolah [2].

Kedua yakni Sistem Informasi Manajemen dan Kepengasuhan Panti Muhammadiyah Jawa Timur Berbasis Web Menggunakan Metode Object Oriented \& Iconic Process". Metode pengembangan perangkat lunak waterfall dan metode pengumpulan data berupa wawancara dan identifikasi dokumen. Sistem informasi yang dibangun memberi kemudahan bagi pihak manajemen Muhammadiyah dalam memonitoring dan mengontrol data seluruh anak panti yang berada di wilayah Jawa Timur [3].

Ketiga yakni Perancangan Sistem Informasi Manajemen Rumah Sakit Berbasis Web Studi Kasus :Rumah Sakit TNI AU Lanud Sam Ratulangi. Metode pengembangan perangkat lunak waterfall dan metode pengumpulan data berupa observasi \& wawancara. Sistem Informasi Manajemen yang telah dihasilkan pada perancangan ini dapat mengelola data pasien rumah sakit untuk rawat jalan, rawat inap, pelayanan apotik dan pelayana kasir. Adapun setiap bagian pelayanan dapat merekap seluruh data pasien maupun data keuangan untuk bagian kasir dan apotik. [4].

Kesamaan dari peneliti di atas dengan sistem yang akan peneliti bangun adalah menghasilkan sistem berbasis web. Kesamaan lain yaitu, bahasa pemograman yang digunakan untuk membangun sistem ialah bahasa pemograman PHP dan database MySql. Adapun perbedaan dari para peneliti di atas adalah sistem yang dibangun hanya terdiri dari satu pengguna yaitu admin, sedangkan sistem yang akan dibangun peneliti memiliki beberapa pengguna yaitu admin, user dan pimpinan. Perbedaan lainnya yaitu sistem yang dibangun peneliti di atas tidak memiliki fitur registrasi user, sedangkan sistem yang akan dibangun peneliti memiliki fitur registrasi user yang digunakan untuk berdonasi secara online. Perbedaan terakhir dari peneliti dengan peneliti di atas ialah terletak pada studi kasusnya.

\section{METODE}

Metode pengumpulan data merupakan metode yang digunakan untuk memperoleh data-data yang diperlukan dalam penelitian dengan menggunakan metode Kualitatif [5] [6]. Adapun metode yang digunakan dalam proses pengumpulan data penelitian ini adalah sebagai berikut:

Pertama yakti tahap wawancara dilakukan untuk mengumpulkan data secara langsung dengan cara melakukan tanya jawab dengan narasumber. Dalam penelitian ini penulis melakukan wawancara tatap muka dengan Bapak Irwan Jayadi, S.Pd selaku Pimpinan Panti Asuhan Muhammadiyah.

Kedua yakni tahap observasi, pada tahap ini penulis melakukan survei lokasi langsung dan melakukan pengamatan terhadap objek penelitian untuk mengumpulkan data-data Panti Asuhan seperti data anak panti, data pengurus, data donatur serta laporan.

Ketiga yakni tahap dokumentasi, pada tahap ini penulis mengambil data berupa gambar atau foto dari buku yang digunakan oleh pengurus panti serta dokumen-dokumen lain tentang pengelolaan panti.

Tahap terakhir yakni tahap studi pustaka dilakukan dengan cara mempelajari referensireferensi seperti buku, jurnal, Bahan Ajar Sistem Informasi Manajemen, Rekayasa Perangkat Lunak dan lainnya, jurnal, artikel dan browsing internet yang berhubungan dengan penelitian ini.

Adapun metode perangkat lunak yang digunakan model waterfall adalah model klasik yang bersifat sistematis, berurutan dalam membangun software, disebut dengan waterfall karena tahapan yang dilalui harus menunggu tahapan sebelumnya dan dieksekusi secara berurutan [7].

Berikut ini tahapan-tahapan dalam pengembangan perangkat lunak menggunakan metode waterfall:

\section{a. Communication}

Pada tahap ini penulis melakukan analisa kebutuhan perangkat keras, kebutuhan perangkat lunak dan kebutuhan data untuk membuat Sistem Informasi Manajemen Panti Asuhan Muhammadiyah Sumbawa Berbasis Web.

\section{b. Planning}

Tahap berikutnya adalah melakukan perencanaan Rekayasa Sistem Informasi Manajemen pada Panti Asuhan Muhammdiyah Sumbawa Berbasis Web dalam waktu 3 bulan. Perencanaan ini meliputi perencanaan waktu dan resiko yang berpeluang terjadi selama proses pembuatan sistem. 


\section{c. Modelling}

Tahapan ini adalah tahap perancangan sistem yang akan dibangun. Perancangan ini meliputi perancangan alur sistem, perancangan basis data dan perancangan tampilan dari Sistem Informasi Manajemen Panti Asuhan Muhammadiyah Sumbawa Berbasis Web.

d. Construction

Tahap ini merupakan proses penerjemah bentuk desain menjadi bahasa pemograman PHP, database MySQL, dan pengujian menggunakan Black Box.

\section{e. Deployment}

Tahapan terakhir merupakan pemeliharaan software secara berkala agar dapat tetap berjalan dan berkembang sesuai dengan fungsinya.

\section{HASIL DAN PEMBAHASAN}

\section{Alur Sistem Berjalan}

Adapun alur proses yang sedang berjalan saat ini dapat dilihat pada gambar berikut:

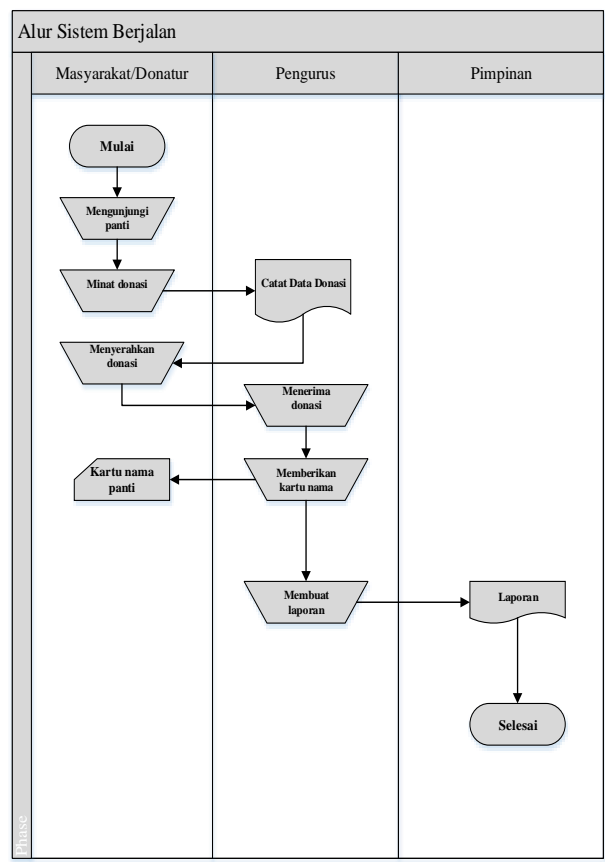

Gambar 1. Alur Sistem Berjalan

\section{Rancangan Sistem Usulan}

Adapun sistem yang diusulkan dapat dilihat pada gambar berikut:

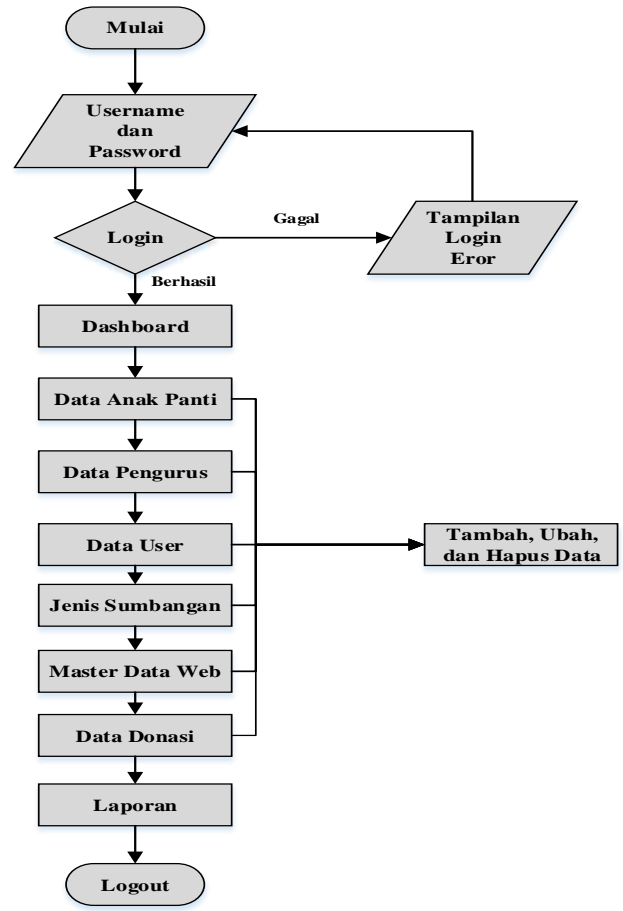

Gambar 2. Sistem Usulan Admin

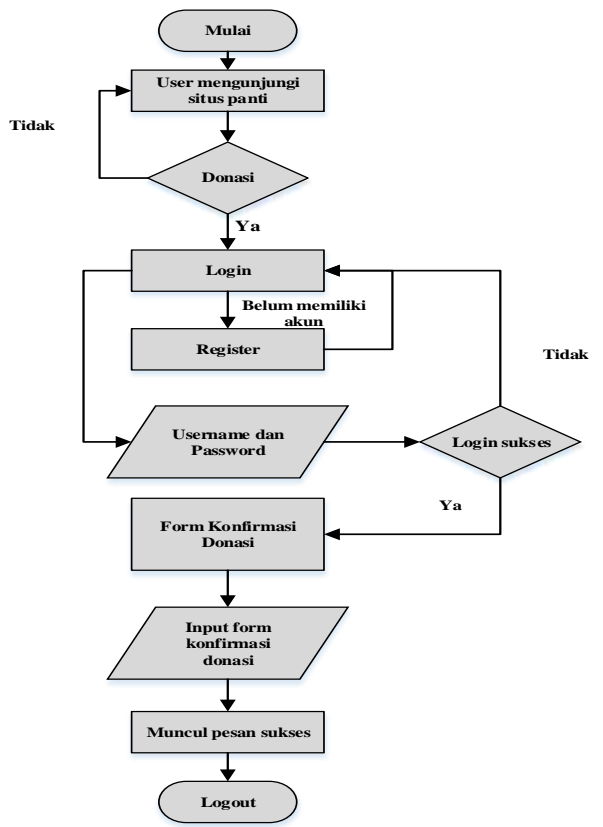

Gambar 3. Sistem Usulan User

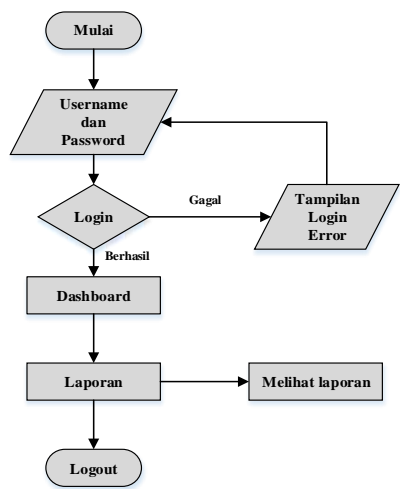

Gambar 4. Sistem Usulan Pimpinan 


\section{Rancangan Sistem}

Adapun rancangan sistem yang dilakukan dalam pembuatan Rekayasa Sistem Informasi Manajemen Panti Asuhan Muhammadiyah Sumbawa Berbasis Web adalah sebagai berikut:

1. Diagram Konteks

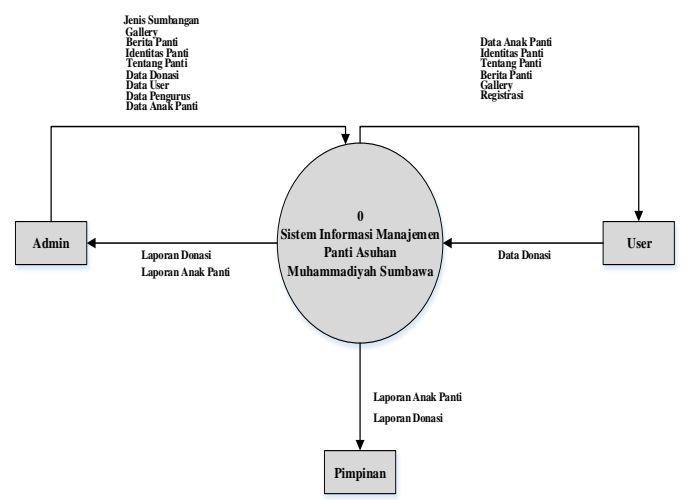

Gambar 5. Diagram Konteks

2. Entity Relationship Diagram (ERD)

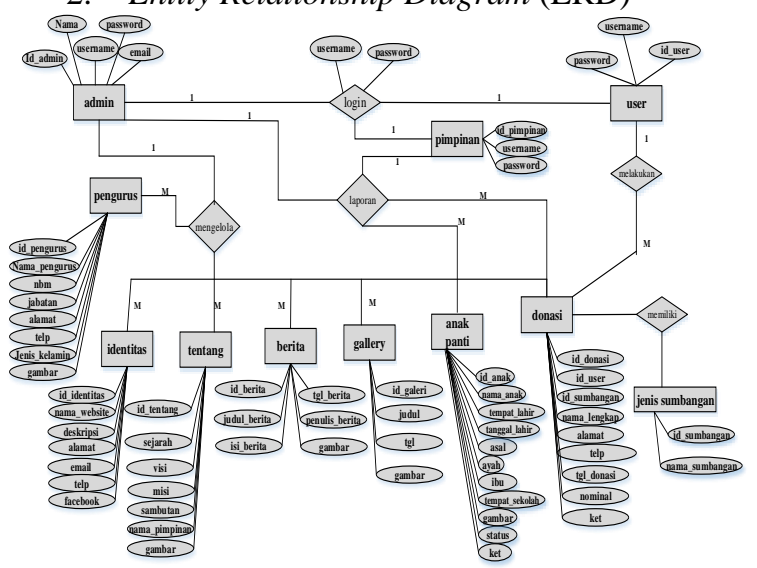

Gambar 6. ERD

3. Relasi Antar Tabel

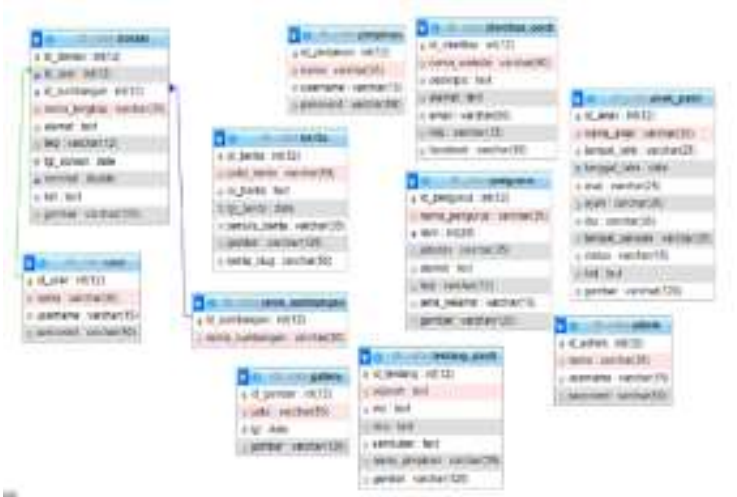

Gambar 7. Relasi Tabel

\section{Implementasi Program}

Adapun implementasi program dalam pembuatan Sistem Informasi Manajemen Panti Asuhan Muhammadiyah Sumbawa adalah sebagai berikut:

\section{Implementasi Antarmuka (Interface) Admin}

a. Antarmuka (Interface) Login

Gambar berikut merupakan tampilan awal ketika pengelola admin akan masuk ke sistem.

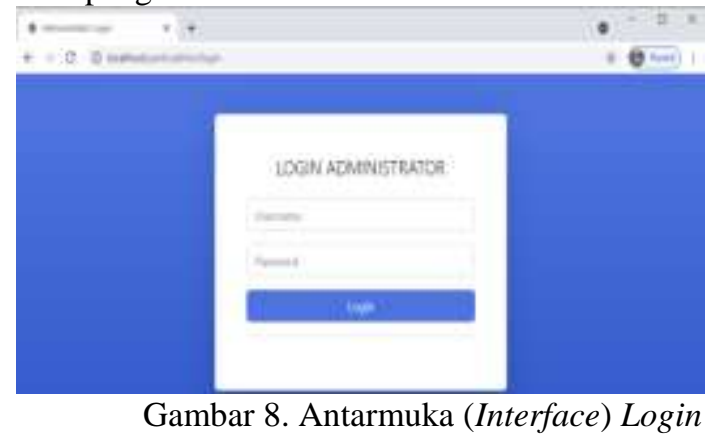

b. Antarmuka (Interface) Dashboard

Gambar berikut merupakan tampilan dashboard ketika admin berhasil login ke sistem.

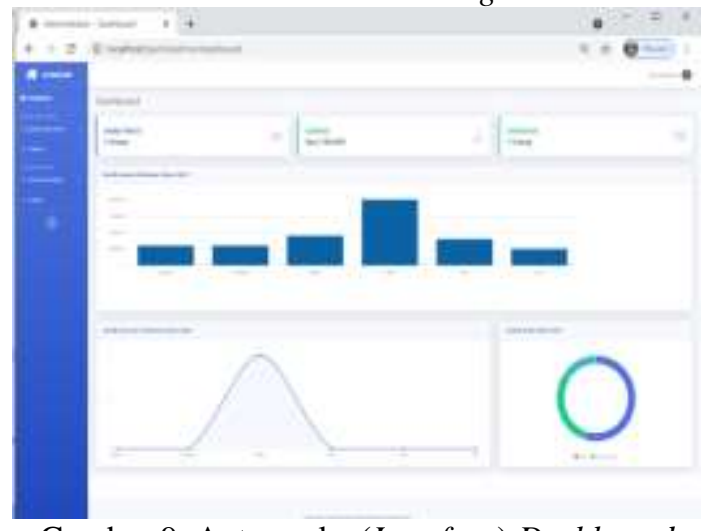

Gambar 9. Antarmuka (Interface) Dashboard

Pada halaman dashboard admin dapat melihat jumlah anak panti, jumlah donasi yang masuk, jumlah donatur, grafik donasi, grafik donator, dan grafik anak panti.

\section{Implementasi Antarmuka (Interface) User}

a. Antarmuka (Interface) Home

Gambar berikut merupakan tampilan halaman home pada saat user pertama kali mengunjungi situs. Pada halaman ini user dapat melihat informasi lengkap mengenai panti dan dapat melakukan donasi secara online. 


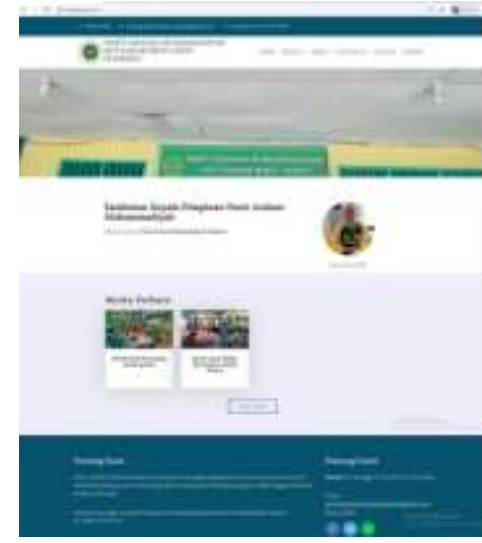

Gambar 10. Antarmuka (Interface) Home

b. Antarmuka (Interface) Konfirmasi Donasi

Gambar berikut merupakan tampilan halaman donasi. Halaman ini merupakan halaman yang menampilkan form donasi setelah user melakukan transfer donasi melaui bank dan button donasi untuk melakukan proses donasi. User dapat memilih button kembali untuk kembali ke halaman home.
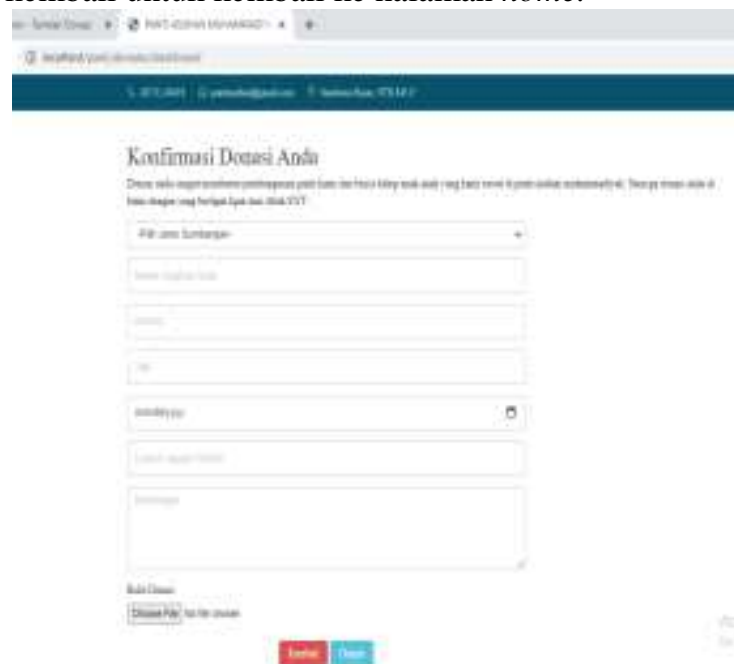

Gambar 11. Antarmuka (Interface) Konfirmasi Donasi

\subsubsection{Implementasi Antarmuka (Interface) Pimpinan}

a. Antarmuka (Interface) Login

Gambar berikut merupakan tampilan halaman login. Halaman ini merupakan tampilan awal ketika pimpinan akan masuk ke sistem.

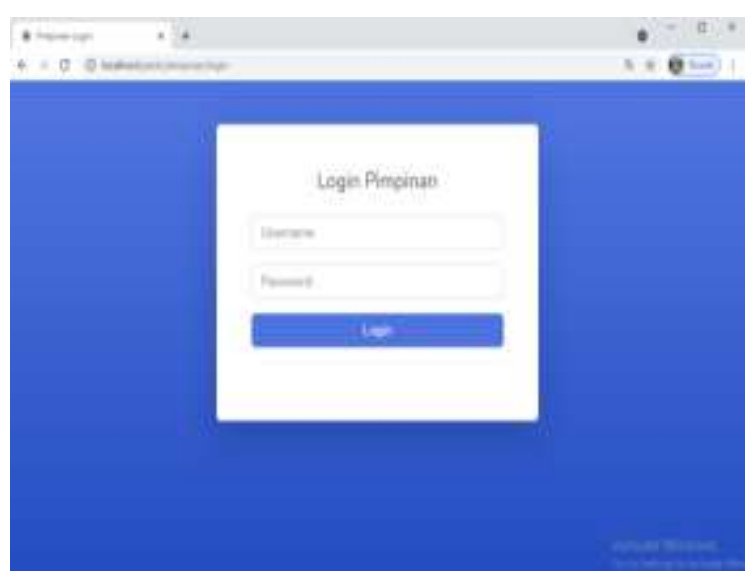

Gambar 12. Antarmuka (Interface) Login Pimpinan

b. Antarmuka (Interface) Dashboard

Gambar berikut merupakan tampilan halaman dashboard. Halaman ini merupakan tampilan awal setelah pimpinan berhasil masuk ke sistem.

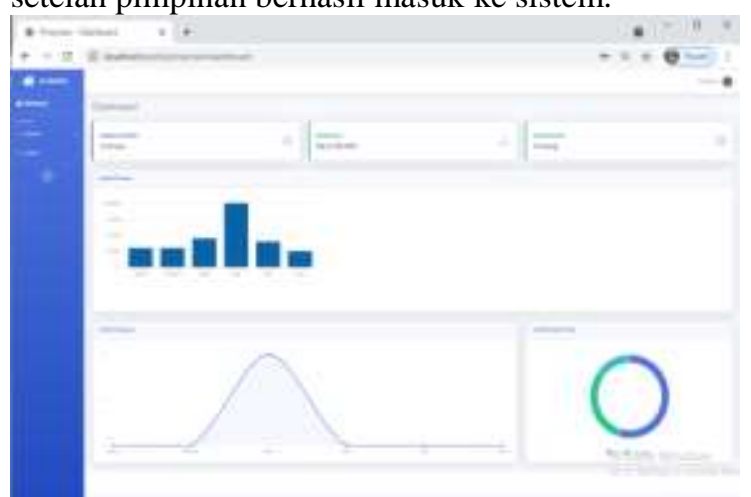

Gambar 13. Antarmuka (Interface) Dashboard

\section{Pengujian Sistem}

Hasil pengujian terhadap Sistem Informasi Manajemen Panti Asuhan Muhammadiyah Sumbawa yang dilakukan oleh ahli, pengurus panti sebgai admin, beberapa responden teman-teman mahasiswa adalah sebagai berikut:

Pengujian User Mengunjungi Situs Tabel 1. Pengujian User Mengunjungi Situs

\begin{tabular}{|c|c|c|c|}
\hline $\begin{array}{c}\text { Aksi } \\
\text { Aktor }\end{array}$ & $\begin{array}{c}\text { Yang } \\
\text { Diharapka } \\
\mathrm{n}\end{array}$ & $\begin{array}{c}\text { Pengama } \\
\text { tan }\end{array}$ & $\begin{array}{c}\text { Kesimpu } \\
\text { lan }\end{array}$ \\
\hline $\begin{array}{c}\text { Masuk } \\
\text { halama } \\
\text { n situs }\end{array}$ & $\begin{array}{c}\text { Menampil } \\
\text { kan } \\
\text { halaman } \\
\text { home }\end{array}$ & Sesuai \\
\hline $\begin{array}{c}\text { Memili } \\
\text { h menu } \\
\text { berita }\end{array}$ & $\begin{array}{c}\text { Menampil } \\
\text { kan } \\
\text { halaman } \\
\text { berita }\end{array}$ & Sesuai \\
\hline $\begin{array}{c}\text { Memili } \\
\text { h menu } \\
\text { gallery }\end{array}$ & $\begin{array}{c}\text { Menampil } \\
\text { kan } \\
\text { halaman } \\
\text { gallery }\end{array}$ & Sess & \\
\hline $\begin{array}{c}\text { Memili } \\
\text { h menu }\end{array}$ & $\begin{array}{c}\text { Menampil } \\
\text { kan }\end{array}$ & & \\
\hline
\end{tabular}




\begin{tabular}{|c|c|c|c|}
\hline $\begin{array}{c}\text { anak } \\
\text { panti }\end{array}$ & $\begin{array}{c}\text { halaman } \\
\text { anak panti }\end{array}$ & & \\
\hline $\begin{array}{c}\text { Memili } \\
\text { h menu } \\
\text { donasi }\end{array}$ & $\begin{array}{c}\text { Menampil } \\
\text { kan } \\
\text { halaman } \\
\text { donasi }\end{array}$ & & Sesuai \\
\hline $\begin{array}{c}\text { Memas } \\
\text { ukkan } \\
\text { userna }\end{array}$ & $\begin{array}{c}\text { Berhasil } \\
\text { login dan } \\
\text { menampilk }\end{array}$ & & \\
me dan & $\begin{array}{c}\text { an halaman } \\
\text { passwo } \\
\text { kd user }\end{array}$ & & \\
\hline $\begin{array}{c}\text { Memas } \\
\text { donasi }\end{array}$ & $\begin{array}{c}\text { Menampil } \\
\text { ukan }\end{array}$ & & \\
data & halaman & & \\
konfir & terima & & Sesuai \\
masi & kasih & & \\
donasi & & & \\
\hline Memili & Berhasil & & \\
h menu & logout dan & & \\
logout & kembali ke & & \\
& halaman & & \\
& home & & \\
\hline
\end{tabular}

Dari hasil pengujian yang dilakukan oleh ahli dari atribut effectiveness, efficiency, serta satisfication dapat disimpulkan bahwa sistem ini sudah sesuai dengan kebutuhan pengguna dan telah layak digunakan. Sedangkan dari hasil pengujian user dapat disimpulkan bahwa sistem ini mudah digunakan dan membantu masyarakat dalam memperoleh informasi yang lengkap dan up to date mengenai panti.

\section{KESIMPULAN DAN SARAN}

Dari hasil analisa dan perencanaan perangkat lunak yang telah dilakukan sebelumnya, maka penulis dapat mengambil kesimpulan bahwa Sistem Informasi Manajemen Panti Asuhan Muhammadiyah Sumbawa telah selesai dibangun dengan menggunakan metode waterfall sebagai metode pengembangan perangkat lunak dan dibangun menggunakan Sublime Text dengan bahasa pemograman PHP serta MySQL sebagai databasenya. Dengan dibangunnya sistem informasi manajemen panti asuhan berbasis web ini, dapat mempermudah pengurus dalam mengelola data panti asuhan serta mempermudah donatur dalam mencari informasi mengenai Panti Asuhan Muhammadiyah.

Sistem Informasi Manajemen Panti Asuhan Muhammadiyah Berbasis Web tentu masih jauh dari kata sempurna dan masih memiliki banyak kekurangan. Oleh karena itu, penulis berharap bagi penulis selanjutnya dapat mempertimbangkan saransaran berikut ini:

1. Meningkatkan keamanan sistem untuk menjaga keamanan data dari pihak yang tidak bertanggung jawab.
2. Kedepannya penulis mengharapkan adanya tambahhan fitur adopsi anak jika ada donatur yang melakukan adopsi anak panti.

\section{DAFTAR PUSTAKA}

[1] Yunanto, A. A. (2020). RANCANG BANGUN SISTEM INFORMASI MANAJEMEN PANTI ASUHAN AL-KAHFI SURABAYA. SCAN-Jurnal Teknologi Informasi Dan Komunikasi, 15(3), 1-5.

[2] Endar NI., NursantiE., \& HandokoF. (2015). Rancangan Sistem Informasi Manajemen Sekolah Berbasis Web Interaktif Terintegrasi Di Smk Negeri 1 Nabire. JURNAL TEKNOLOGI DAN MANAJEMEN INDUSTRI, 1(1), 53-59.

[3] Inayati IM., Farida H. (2017). Analisa Desain SIMPM - Sistem Informasi Manajemen Dan Kepengasuhan Panti Muhammadiyah Jawa Timur Berbasis Web Menggunakan Metode Object Oriented Dan Iconic Proses. Jurnal SENTIA, 27(2), 1-6.

[4] Topan, Mohamad, Hans F. Wowor, and Xaverius B. N. Najoan. 2015. "Perancangan Sistem Informasi Manajemen Rumah Sakit Berbasis Web Studi Kasus : Rumah Sakit TNI AU Lanud Sam Ratulangi.” E Journal Teknik Informatika 6(1):1-6.

[5] Anggito, A., \& Setiawan, J. (2018). Metode Penelitian Kualitatif. CV. JEJAK.

[6] Fitrah, M., \& Luthfiyah. (2017). Metodologi Penelitian; Penelitian Kualitatif, Tindakan Kelas \& Studi Kasus. CV. JEJAK.

[7] Pressman, R.S. 2015. Rekayasa Perangkat Lunak: Pendekatan Praktisi Buku 1. Yogyakarta: ANDI. 